\title{
Enhanced expression of codon optimized Mycobacterium avium subsp. paratuberculosis antigens in Lactobacillus salivarius
}

\section{Christopher D. Johnston ${ }^{1}$, John P. Bannantine ${ }^{2}$, Rodney Govender $^{1}$, Lorraine Endersen $^{1}$, Daniel Pletzer ${ }^{3}$, Helge Weingart $^{3}{ }^{3}$ Aidan Coffey ${ }^{1}$, Jim O'Mahony $^{1 *}$ and Roy D. Sleator ${ }^{1}$}

\author{
${ }^{1}$ Biological Sciences Department, Cork Institute of Technology, Cork, Ireland \\ 2 United States Department of Agriculture - Agricultural Research Service, National Animal Disease Center, Ames, IA, USA \\ ${ }^{3}$ School of Engineering and Science, Jacobs University Bremen, Bremen, Germany
}

\section{Edited by:}

Adel M. Talaat, University of

Wisconsin-Madison, USA

Reviewed by:

Martin S. Pavelka, University of Rochester, USA

Jan Peter Van Pijkeren, University of

Wisconsin-Madison, USA

*Correspondence:

Jim O'Mahony, Department of Biological Sciences, Cork Institute of

Technology, Rossa Avenue,

Bishopstown, Cork, Ireland

e-mail:jim.omahony@cit.ie
It is well documented that open reading frames containing high GC content show poor expression in $\mathrm{A}+\mathrm{T}$ rich hosts. Specifically, $\mathrm{G}+\mathrm{C}$-rich codon usage is a limiting factor in heterologous expression of Mycobacterium avium subsp. paratuberculosis (MAP) proteins using Lactobacillus salivarius. However, re-engineering opening reading frames through synonymous substitutions can offset codon bias and greatly enhance MAP protein production in this host. In this report, we demonstrate that codon-usage manipulation of MAP2121c can enhance the heterologous expression of the major membrane protein (MMP), analogous to the form in which it is produced natively by MAP bacilli. When heterologously over-expressed, antigenic determinants were preserved in synthetic MMP proteins as shown by monoclonal antibody mediated ELISA. Moreover, MMP is a membrane protein in MAP, which is also targeted to the cellular surface of recombinant L. salivarius at levels comparable to MAP. Additionally, we previously engineered MAP3733c (encoding MptD) and show herein that MptD displays the tendency to associate with the cytoplasmic membrane boundary under confocal microscopy and the intracellularly accumulated protein selectively adheres to the MptD-specific bacteriophage $f M p t D$. This work demonstrates there is potential for $L$. salivarius as a viable antigen delivery vehicle for MAP, which may provide an effective mucosal vaccine against Johne's disease.

Keywords: MAP antigens, MptD, MMP, codon optimization, expression host, paratuberculosis, MAP vaccine, Johne's disease

\section{INTRODUCTION}

Mycobacterium avium subsp. paratuberculosis (MAP) is an intracellular pathogen and the etiological agent of Johne's disease, a chronic inflammatory disorder of the gastrointestinal tract which affects multiple ruminant species including cattle (Chacon et al., 2004). Live attenuated vaccine formulations against Johne's disease do not appear to offer adequate protection against MAP infection in goats (Hines et al., 2014) and while heat-killed whole cell vaccines that are commercially available do show some efficacy, these also fail to provide full protection against MAP in models of infection (Rosseels and Huygen, 2008). Moreover, issues relating to interference with diagnostic assays for bovine tuberculosis have further hindered their widespread development and application (Buddle et al., 2010; Bastida and Juste, 2011; Coad et al., 2013). These limitations combined with the availability of complete genome sequences for MAP (Li et al., 2005; Bannantine et al., 2014) have focused recent attention on experimental subunit based vaccine strategies against MAP (Bull et al., 2007; Rosseels and Huygen, 2008). One particularly promising subunit vaccine for MAP is the $70 \mathrm{kDa}$ heat shock protein termed
Hsp70 (Koets et al., 2006), which activates B cells (Vrieling et al., 2013).

Lactobacillus are interesting candidates for the development of novel oral vaccine vectors due to certain strains widespread use in the food industry and GRAS (generally regarded as safe) status (Yu et al., 2013). Specific members of this genus are also an attractive alternative to using attenuated pathogens for mucosal delivery strategies because they can survive the upper gastrointestinal tract (GI) and colonize the lower GI tract (Bermudez-Humaran et al., 2011). Numerous studies have substantiated the potential of specific Lactobacilli strains to serve as live vaccine delivery vehicles against a broad spectrum of mucosal pathogens including Bacillus anthracis, Streptococcus pneumonia, Clostridium difficile and the Avian Influenza Virus H5N1 (Campos et al., 2008; Sleator and Hill, 2008; Mohamadzadeh et al., 2010; Wang et al., 2012). MAP is particularly well-suited to Lactobacillus vector delivery because it is a pathogen transmitted by ingestion of contaminated feces or milk and passes through the GI tract where it infects the intestinal mucosa (Bannantine and Bermudez, 2013). 
However, despite the obvious advantages of Lactobacillus based mucosal immunization; encompassing the inherent ability of specific strains to survive gastric transit, adhere to the intestinal epithelium (Messaoudi et al., 2012), and stimulate both mucosal and systemic immune responses (Mohamadzadeh et al., 2009), there are known difficulties in expression of $\mathrm{G}+\mathrm{C}$ rich coding sequences in the $\mathrm{A}+\mathrm{T}$ rich Lactobacillus host (Johnston et al., 2013). Indeed, we recently determined that the significantly divergent genomic $\mathrm{G}+\mathrm{C}$ content of MAP and Lactobacillus salivarius (69 and 33\% respectively) leads to a disparity in codon usage, which significantly impedes recombinant MAP protein synthesis. To alleviate this translation inefficiency likely due to ribosomal pausing at rare codons (Buchan and Stansfield, 2007), codon optimization of a MAP gene (MAP3733c) was performed by introducing a series of synonymous mutations; modifying the coding region to better suit the codon bias of $L$. salivarius. It was shown that synthesis of a MAP specific membrane protein within L. salivarius could be markedly enhanced ( $>37$ fold) owing to codon optimization, resulting in the abundance of MAP-GFP protein fusion fluorescence in recombinant cells (Johnston et al., 2013). However, that protein was never confirmed to truly represent the native protein as no monoclonal antibodies or other specific detection reagents were developed against it.

Because MAP surface proteins likely play the dominant role in the initial interactions with bovine intestinal cells (Bannantine et al., 2003; He and De Buck, 2010; Gurung et al., 2012), we here focused on two important MAP membrane proteins, MMP (MAP2121c) and the previously studied MptD (MAP3733c). MMP, encoded by MAP2121c, is a $\sim 33.5 \mathrm{kDa}$ surface protein which shares homology to a Mycobacterium leprae 35-kDa major membrane protein-1 (MMP-1) (Winter et al., 1995), previously identified as a potent immunodominant antigen capable of inducing T-lymphocyte responses in paucibacillary leprosy patients (Triccas et al., 1996). MptD is a MAP specific, virulence associated membrane protein which is surface expressed during natural infection, warranting its further investigation as a prophylactic antigen (Stratmann et al., 2004; Shin et al., 2006; Cossu et al., 2011).

A significant limitation of current whole cell MAP vaccine strategies is interference with cellular immune assays and tuberculin skin tests for bovine tuberculosis (M. bovis), which restricts their widespread application in many countries (Kohler et al., 2001; Scandurra et al., 2010). It is notable that although MMP is not specific to MAP, with homologs existing in other mycobacterial species including M. avium (MAC) and M. leprae, previous genetic and serological evidence suggests that the protein is absent from M. tuberculosis and M. bovis (Triccas et al., 1998; Banasure et al., 2001). In addition, a DNA vaccine incorporating the M. leprae MMP-1 protein in isolation demonstrated significant levels of protective efficacy against $M$. leprae footpad infection in outbred Swiss Albino mice (Martin et al., 2001). As such, if an MMP-based vaccine against Johne's disease were to display strong prophylactic efficacy, as it has done against Leprosy, it leads to the exciting prospect of a vaccine formulation that could overcome issues with interference of bovine tuberculosis screening assays.
Herein, we analyzed MAP proteins recoded using synonymous substitutions and expressed in L. salivarius. Faithful expression and antigenicity was examined using a combination of fluorescence microscopy, monoclonal antibody- and bacteriophage-based ELISA.

\section{MATERIALS AND METHODS}

\section{STRAINS, PLASMIDS, BACTERIOPHAGE, AND GROWTH CONDITIONS}

The strains and plasmids used in this study are listed in Table 1. Mycobacterium avium subsp. paratuberculosis strain K10 (ATCC BAA968) were propagated in Middlebrook 7H9 broth supplemented with OADC (BD Biosciences), $2 \mu \mathrm{g} / \mathrm{ml}$ of Mycobactin $\mathrm{J}$ and $0.2 \%$ glycerol and incubated at $37^{\circ} \mathrm{C}$ for 6-10 weeks. Escherichia coli DH5 $\alpha$ electrocompetent cells (Invitrogen) were used as intermediate cloning hosts for all vector constructs within this study and grown at $37^{\circ} \mathrm{C}$ in Luria-Bertani (LB) media. Lactobacillus salivarius NRRL B30514 (kindly donated by Dr. Norman Stern, USDA), was used throughout this study as the host for individual vector constructs and was grown aerobically at $37^{\circ} \mathrm{C}$ in MRS media (Fluka).

Plasmids pNZ9530 and pNZ8048 were originally obtained from the University College Cork culture collection, while pUC57 vectors containing codon-optimized synthetic GFP and MptDsynth genes were obtained from the Cork Institute of Technology culture collection (Johnston et al., 2013). Cultures of E. coli harboring individual vectors were supplemented with Erythromycin (Ery, $200 \mu \mathrm{g} / \mathrm{ml})$, Chloramphenicol $(\mathrm{Cm}$, $12.5 \mu \mathrm{g} / \mathrm{ml}$ ), or Ampicillin (Amp, $200 \mu \mathrm{g} / \mathrm{ml}$ ) for pNZ9530, pNZ8048, and pUC57 containing cells respectively. Recombinant L. salivarius cells were subcultured from $40 \% \mathrm{v} / \mathrm{v}$ glycerol stocks at $-20^{\circ} \mathrm{C}$ and grown using antibiotic selection. L. salivarius (pNZ9530) cultures were supplemented with $5 \mu \mathrm{g} / \mathrm{ml}$ Ery, while L. salivarius harboring both pNZ9530 and pNZ8048 constructs were grown in the presence of $5 \mu \mathrm{g} / \mathrm{ml}$ Ery and $10 \mu \mathrm{g} / \mathrm{ml} \mathrm{Cm}$.

The M13 phage $\mathrm{AMptD}$, originally isolated from the Ph.D. -12 phage display library (New England Biolabs), was obtained from the laboratory of Gerald F. Gerlach (University of Veterinary Medicine, Hanover, Germany). Bacteriophage $\mathrm{fMptD}$ was propagated using standard methods previously described (Chappel et al., 1998). Phage titers were assessed by a standard plaque assay test (Sambrook et al., 1990). Purified high titer phage solutions $\left(10^{10} \mathrm{pfu} / \mathrm{ml}\right)$ were stored at $4^{\circ} \mathrm{C}$ until required.

\section{NUCLEIC ACID ISOLATION}

Mycobacterial DNA was prepared as described previously by Douarre et al. (2010). Plasmid DNA was isolated from E. coli DH5 $\alpha$ using a plasmid extraction kit as per the manufacturer's instructions (Sigma Aldrich). Plasmid isolation from Lactobacillus strains was also carried out using this kit, after initial incubation $\left(30 \mathrm{~min}\right.$ at $\left.37^{\circ} \mathrm{C}\right)$ in protoplast buffer $(20 \mathrm{mM}$ Tris- $\mathrm{HCl}, 5 \mathrm{mM}$ EDTA, $0.75 \mathrm{M}$ Sucrose, $10 \mathrm{mg} / \mathrm{ml}$ lyzozyme and $50 \mathrm{U} / \mathrm{ml}$ mutanolysin $\mathrm{pH}$ 7.5). Quantitative analysis was carried out using microspectrophotometry (Nanodrop, De, USA) and plasmid DNA concentration was normalized to $250 \mathrm{ng} / \mu \mathrm{l}$. 
Table 1 | Strains, Phage, and Plasmids used in this study.

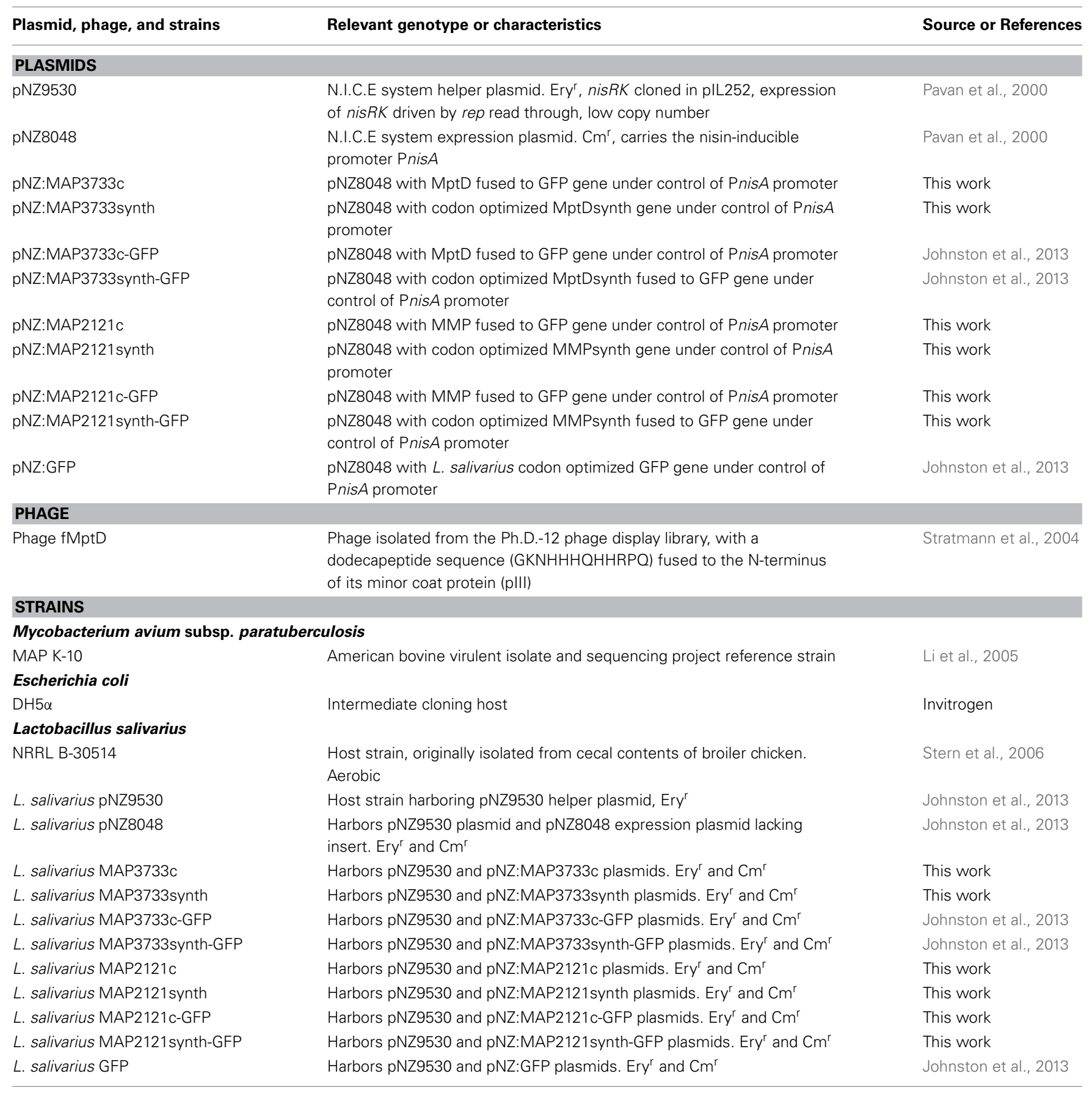

\section{CODON OPTIMIZATION OF MAP2121C}

MAP2121c encodes a major membrane protein (MMP) in MAP. Because this protein has been implicated in the early events of infection in the bovine intestinal musoca, it is an ideal candidate for testing expression in $L$. salivarius as a potential mucosal vaccine. We have previously described a strategy for the codon optimization of the MAP3733c gene for expression in L. salivarius (Johnston et al., 2013). Here we used the same strategy for MAP2121c; briefly, a bioinformatics analysis was performed to identify codons from MAP2121c that could be modified at the third base position without a change in the resulting amino acid (termed a synonymous substitution). Coding sequences were synthesized by GenScript USA Inc. (Piscataway, NJ). Constructs were cloned as described below and confirmed by DNA sequencing. Final sequences for each gene are available from GenBank (Accession numbers: KC854397 and KC517484). All modifications to MAP2121c are summarized in Table 2. 
Table 2 | Modification and codon optimization of MAP genes.

\begin{tabular}{lccccc}
\hline Gene & $\begin{array}{c}\text { Length } \\
\text { (bp) }\end{array}$ & $\begin{array}{c}\text { G+C } \\
\text { content }\end{array}$ & $\begin{array}{c}\text { Unfavorable } \\
\text { codons* }\end{array}$ & $\begin{array}{c}\text { Modified } \\
\text { codons }\end{array}$ & Source \\
\hline MAP2121c & 924 & $66.5 \%$ & $276 / 307$ & $0 / 307$ & This work \\
MAP2121synth & 924 & $32.8 \%$ & $7 / 307$ & $279 / 307$ & This work \\
\hline
\end{tabular}

${ }^{*}$ Codons were deemed unfavorable due to the presence of a guanine or cytosine within the 3rd base of the triplet.

\section{PCR AMPLIFICATIONS AND MODIFICATIONS}

PCR primers are listed in Supplementary Table S1. Primers were designed for the native and codon optimized MAP genes (MAP2121c, MAP3733c, MAP2121synth, and MAP3733synth) based on either MAP strain K-10 sequence data available from the NCBI database (NC_002944) or using the sequence from GenScript synthesized genes. All conventional PCR reactions were carried out using high fidelity Velocity DNA polymerase Kit (Bioline) in accordance with the manufacturer's instructions. Restriction enzymes and T4 DNA ligase were purchased from Roche Diagnostics (Mannheim, Germany) and New England Biolabs (Beverly, MA, USA) and used as per manufacturer's recommendations. Ligation reaction mixtures were purified using the High Pure PCR product purification kit (Roche).

\section{MAP GENE AND FUSION CONSTRUCTS}

Individual MAP gene constructs (native and synthetic) were cloned into the E. coli-L. lactis shuttle vector pNZ8048, a derivative of pNZ124 that allows expression of proteins under the control of the nisin-inducible promoter PnisA, part of the NIsin Controlled Expression (NICE) system (Pavan et al., 2000). Nisin induced expression was achieved in L. salivarius via cotransformation of a dual plasmid system; pNZ8048 with insert to be expressed downstream of PnisA and pNZ9530 providing the necessary nisRK regulatory genes in trans (de Ruyter et al., 1996).

Two native MAP genes, MAP2121c and MAP3733c (designated " $\mathrm{c}$ " to indicate that each is originally transcribed on the complimentary strand of the MAP K-10 genome) and two synthetic codon optimized counterparts of these, designated MAP2121synth and MAP3733synth, were initially cloned forming pNZ:2121c, pNZ:3733c, pNZ:2121synth, and pNZ:3733synth. To facilitate fluorometric analysis of each of these genes during expression and monitor subcellular localization of proteins within the host cell, a C-terminus GFP gene was translationally fused to each gene construct forming pNZ:2121c-GFP, pNZ:3733cGFP, pNZ:2121synth-GFP, and pNZ:3733synth-GFP. The fusion of GFP and individual MAP genes was performed using Splicing by Overlap Extension (SOEing) as previously described (Johnston et al., 2013).

The GFP coding region used for fusions throughout this study was codon optimized for use within L. salivarius. The GFP gene sequence cloned into pNZ8048 (Johnston et al., 2013) was used to provide a comparative control for subsequent assays and designated pNZ:GFP.

\section{TRANSFORMATION AND INDUCTION OF L. SALIVARIUS CONSTRUCTS}

Competent L. salivarius (pNZ9530) were transformed individually with each of the MAP gene constructs (Table 1) as described previously (Johnston et al., 2013). Overnight cultures of recombinant $L$. salivarius strains were subcultured (1:100 dilution) into fresh MRS broth $(\mathrm{Cm} 8 \mu \mathrm{g} / \mathrm{ml}$, Ery $3.5 \mu \mathrm{g} / \mathrm{ml})$ and incubated with agitation $(100 \mathrm{rpm})$ at $37^{\circ} \mathrm{C}$. At an optical density $\left(\mathrm{OD}_{600 \mathrm{~nm}}\right)$ of 0.35 , nisin was added at a final concentration of $10 \mathrm{ng} / \mathrm{ml}$ and cultures were incubated statically at $37^{\circ} \mathrm{C}$ for $2 \mathrm{~h} .10 \mathrm{ml}$ aliquots of each culture were then harvested by centrifugation ( $6000 \mathrm{rpm}$ for $5 \mathrm{~min}$ ) for subsequent analysis.

\section{FLUORESCENCE MICROSCOPY}

To facilitate visualization of cells using fluorescence microscopy, induced L. salivarius strains (L.sal GFP, L.sal MAP2121cGFP, L.sal MAP2121synth-GFP, L.sal MAP3733c-GFP, L.sal MAP3733synth-GFP) were fixed using 3.7\% formaldehyde, washed with $\mathrm{PBS}(\mathrm{pH} 7.2$ ), subsequently resuspended in $1 \mathrm{ml}$ PBS and stored at $4^{\circ} \mathrm{C}$ until visualized. For detection of GFP fusion peptides, $L$. salivarius cell images were taken using a Zeiss LSM 510 META laser-scanning microscope equipped with Argon and Helium-Neon lasers (Carl Zeiss, Oberkochen, Germany) at a resolution of $2048 \times 2048$ pixels, using LSM 5 software (version 3.2; Carl Zeiss). Equal settings were used for detection of green fluorescence among different strains (Amplifier Offset: 0.05, Amplifier Gain: 1, Gain: 820).

\section{PREPARATION OF WHOLE CELL L. SALIVARIUS FOR ELISA}

To determine if recombinant MMP and MMPsynth peptides were displayed on the surface of whole cell $L$. salivarius, nisininduced strains were harvested, washed and resuspended in PBS and coated directly to the wells of a Nunc Maxisorp plate $(1 \times$ $10^{9} \mathrm{cells} / \mathrm{ml}$ ). To determine if these peptides were accumulating within the cytoplasm of L. salivarius, $500 \mu \mathrm{l}$ of the harvested cells were transferred to $2 \mathrm{ml}$ screw cap tubes with $0.3 \mathrm{~g}$ glass beads (Sigma, 150-212 $\mu \mathrm{m}$, acid washed) and lysed (4000 rpm for $45 \mathrm{~s}$ ) using a MagNA Lyser Instrument (Roche). Subsequently, $100 \mu \mathrm{l}$ aliquots of crude cell lysate were added to individual wells of the same Maxisorp plate.

In the analysis of $\mathrm{MptD}$ proteins, similar techniques were applied for whole-cell and cell-lysate preparations, however, use of the alternative bacteriophage ( $\mathrm{fMptD}$ ) detection method necessitated the substitution of PBS for TBS in all washing and subsequent steps. MAP strain K-10, processed in the same manner, was included in all assays to provide a comparative control.

\section{MONOCLONAL ANTIBODY BASED ELISA OF MMP}

Maxisorp plates containing recombinant $L$. salivarius ( $\mathrm{pNZ}$, MMP, MMPsynth, MMP-GFP, and MMPsynth-GFP), as well as MAP K-10, whole cells and cell lysate were incubated at $37^{\circ} \mathrm{C}$ for $1 \mathrm{~h}$ and then blocked with a $5 \%(\mathrm{w} / \mathrm{v})$ solution of dry skimmed milk powder in PBS. A $100-\mu l$ aliquot of purified monoclonal antibody 13E1 or 8G2, appropriately diluted in PBS plus $0.1 \%$ tween $20(\mathrm{PBS} / \mathrm{T})$ was added to each test well. Samples were incubated at $37^{\circ} \mathrm{C}$ for $1 \mathrm{~h}$ on a rocking platform. The wells were washed and $100 \mu \mathrm{l}$ of secondary antibody (Peroxidase-labeled, Anti-Mouse IgG detection antibody) diluted in PBS/T containing $1 \%(\mathrm{w} / \mathrm{v})$ milk powder was added. After a $1 \mathrm{~h}$ incubation at $37^{\circ} \mathrm{C}$ the wells were washed and $100 \mu \mathrm{l}$ of $3,3^{\prime}, 5,5^{\prime}$ Tetramethylbenzidine Liquid Substrate System for ELISA (Sigma) 
was added per well. The substrate was left to develop in the dark at room temperature for $30 \mathrm{~min}$ after which the reaction was stopped by addition of $50 \mu \mathrm{l}$ of a $10 \% \mathrm{HCl}$ solution. Absorbance readings were read at $450 \mathrm{~nm}$ using a microplate reader. The binding response values against each respective recombinant cell type were normalized by dividing the absorbance level obtained in test wells by that obtained in parallel control wells treated with diluent buffer without the addition of the primary monoclonal antibody.

\section{BACTERIOPHAGE-fMptD BASED ELISA OF MptD}

Due to a lack of monoclonal antibodies available for the MptD protein, the $\mathrm{fMptD}$ bacteriophage (Stratmann et al., 2006) was used in lieu of the primary binding antibody within MptD ELISA. Maxisorp plates containing recombinant L. salivarius (pNZ, MptD, MptDsynth, MptD -GFP, and MptDsynth-GFP), as well as MAP K-10, whole cells and cell lysate were incubated at $37^{\circ} \mathrm{C}$ for $1 \mathrm{~h}$ and then blocked with a $5 \%(\mathrm{w} / \mathrm{v})$ solution of dry skimmed milk powder in TBS. Plates were washed with TBS/T (TBS $+0.1 \%[\mathrm{v} / \mathrm{v}]$ Tween-20) and $100 \mu \mathrm{l}$ of $\mathrm{fMptD}$ $\left(10^{9} \mathrm{pfu} / \mathrm{ml}\right)$ diluted in TBS/T was added to each test well after which samples were incubated at $37^{\circ} \mathrm{C}$ for $1 \mathrm{~h}$ on a rocking platform. Individual wells were subsequently washed and $100 \mu \mathrm{l}$ of the detection antibody, HRP Conjugated anti-M13 monoclonal antibody (GE Healthcare), diluted in TBS/T containing $1 \%(\mathrm{w} / \mathrm{v})$ milk powder was added. After $1 \mathrm{~h}$ incubation at $37^{\circ} \mathrm{C}$ the wells were washed, $100 \mu \mathrm{l}$ of TMB Liquid Substrate (Sigma) was added per well and color developed as already described.

\section{STATISTICAL ANALYSIS}

Statistical analysis was carried out using GraphPad Prism (version 4.03; GraphPad Software, San Diego, CA). Means with standard error (s.e.m.) are presented in each graph. Differences between two groups were calculated using unpaired Student's $t$-test. Differences were considered significant at $P<0.05$.

\section{RESULTS}

\section{DISTINCT LOCALIZATION OF MAP-GFP FUSION PEPTIDES}

In our previous work we confirmed poor fluorescence for the native MptD-GFP fusion protein expressed in L. salivarius, and showed markedly improved expression through codon optimization of the synthetic gene (MptDsynth-GFP; Figures 1E,F) (Johnston et al., 2013). Here, consistent with our previous findings for MptD, induction and confocal microscopy of the native MMP-GFP fusion resulted in no fluorescence (Figure 1C) similar to the L. salivarius wild type control (Figure 1A). In contrast, improved levels of fluorescence were noted for codon optimized MMPsynth-GFP after induction under identical conditions as the native variant (Figure 1D).

While an even distribution of strong fluorescence was observed within pNZ:GFP-containing bacilli (Figure 1B), both engineered MAP fusion displayed different fluorescence patterns when expressed within L. salivarius (Figures 1D,F). MMPsynth-GFP was aggregated (Figure 1D) whereas MptD was more uniformly distributed around the periphery of the cells (Figure 1F).

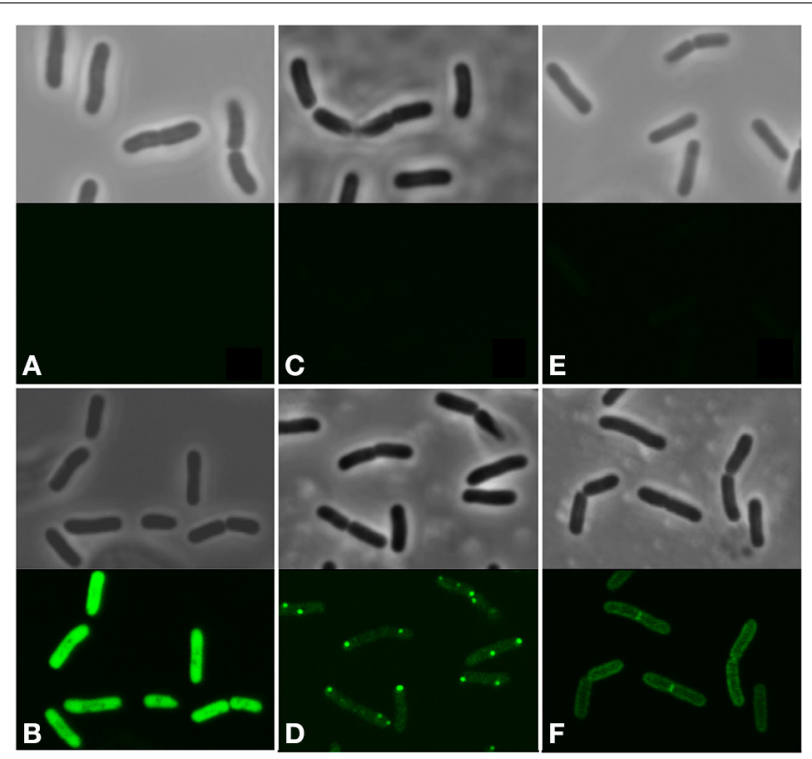

FIGURE 1 | Representative phase contrast (upper panel) and fluorescent microscopy (lower panel) images of recombinant L. salivarius cells. (A) Control cells pNZ:8048. (B) L. salivarius GFP cells displayed fluorescence observed throughout individual bacilli. (C) Negligible levels of fusion fluorescence were observed from MMP-GFP cells, (D) while fluorescent foci, suggestive of aggregation, were observed toward the polar regions of individual cells for the codon optimized variant MMPsynth-GFP. (E) Low levels of fluorescence prevented determination of the subcellular localization of native MptD-GFP fusions within L. salivarius cells, while (F) codon optimized MptDsynth-GFP fusion proteins demonstrated the tendency to localize toward the cellular membrane periphery. All culture assays were performed in triplicate, multiple images were taken from each sample and representative pictures were chosen. Bars represent $5 \mu \mathrm{m}$.

\section{MptD-GFP (MAP3733c/synth)}

In silico TMHMM analysis of $\mathrm{MptD}$ suggests the presence of six transmembrane segments (TMSs) within the 208 amino acids and a large external loop at positions 147-175, with both $\mathrm{N}$ and $\mathrm{C}$ termini being cytoplasmic associated. In cases where transmembrane proteins have their native C-terminus located in the cytoplasm, fusion of a GFP tag is particularly useful for analysis of protein localization. If the fusion is expressed at the cytoplasmic membrane the GFP peptide may fold correctly and fluoresce allowing visualization of protein localized at this membrane, however if it aggregates and forms inclusion bodies the downstream GFP might not fold correctly and therefore not fluoresce (Drew et al., 2005), although this will be largely protein dependant.

The MptDsynth-GFP fusion peptides demonstrated a tendency to localize at the periphery of individual cells (Figure 1F), suggestive of membrane domain insertion and conformation. This result extends our initial findings with $\mathrm{MptD}$ (Johnston et al., 2013).

\section{MMP-GFP (MAP2121c/synth)}

Confocal microscopy of $L$. salivarius MMP-GFP resulted in undetectable fluorescence from individual bacilli (Figure 1C), further supporting our previous hypothesis that native MAP 
genes are poorly translated within L. salivarius. However, fluorescent foci were observed within the re-engineered sequence (MMPsynth-GFP) suggesting the presence of aggregated GFP fusion proteins within the cytoplasm of $L$. salivarius (Figure 1D). This result was not expected since MMP was predicted to be more soluble than MptD using SOLpro1.0 software (Magnan et al., 2009).

\section{RECOMBINANT MptD ACCUMULATES WITHIN THE CYTOPLASM OF L. SALIVARIUS}

To investigate whether the $L$. salivarius expressed MptD protein was analogous to the native MAP protein, we utilized a modified version of the $\mathrm{AMptD}$ bacteriophage mediated ELISA protocol outlined by Rosu et al. (2009), to probe both wholecell and cell-lysates of recombinant $L$. salivarius transformed with both MptD-GFP gene constructs. Two constructs lacking the GFP fusion were also included to control for potential interference from the tag (Figures 2A,B).

Investigation of the crude cell lysates (Figure 2A) from recombinant $L$. salivarius revealed MptD phage binding to both native and codon optimized MptD constructs lacking a GFP fusion tag with a 2.2-fold increase in signal observed for the codon optimized variant over native $(P=0.0008)$, and 2 -fold when compared to MAP K-10 $(P=0.0007)$. Interestingly, in a manner similar to MMP analysis, the addition of a GFP fusion to each of these constructs appears to have effectively inhibited phage binding, possibly by masking the MptD epitope with GFP or prevention of a conformational structure from forming.

Based on the results from confocal microscopy (Figure 1F), we also examined intact cells (Figure 2B) to determine if the tendency of $\mathrm{MptD}$ to localize toward the periphery of L. salivarius represented true surface exposure. However, despite abundant concentrations of $\mathrm{MptD}$ detected within the cytoplasm, no signal $(P=<0.05$ vs. control) could be detected from unbroken cells expressing either native or re-engineered $\mathrm{MptD}$ in the presence or absence of a GFP tag. MptD was detected at similar levels in MAP regardless of the cell preparation (Figures 2A,B).

\section{RE-ENGINEERED MMP DISPLAYS TWO DISTINCT EPITOPES}

The aggregation observed during confocal microscopy of MMPsynth-GFP prompted further investigation of MMP folding within the $L$. salivarius host. To examine the possibility that the C-terminus GFP tag was itself associating with the MMP peptide, potentially leading to the fluorescent aggregates observed (Figure 1D): two additional constructs, L. salivarius with native and codon optimized MMP genes lacking a GFP fusion (pNZ:MAP2121c and pNZ:MAP2121synth), were included in the assays.

Antigenic determinants or epitopes which are recognized on a target protein by an antibody can exist in multiple forms ranging from linear, present on both native or misfolded peptides, to discontinuous or conformationally complex epitopes which are displayed through the native folding of a protein (Brown et al., 2011). In this study, ELISA analysis was performed using two monoclonal antibodies specific to the MMP protein (8G2 and 13E1), which detected two distinct epitopes (Bannantine et al., 2007).

\section{ELISA analysis with $\mathbf{m A b} \mathbf{8 G 2}$ (linear epitope)}

The $8 \mathrm{G} 2$ antibody is reported to associate with a linear epitope present within a 77 -amino acid sequence near the $\mathrm{N}$-terminus

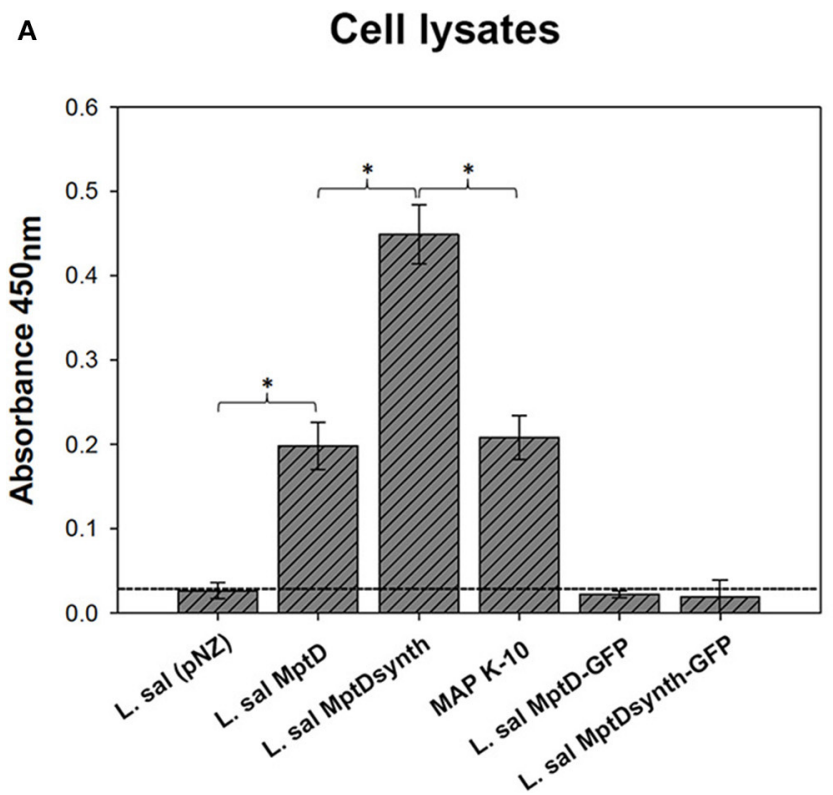

FIGURE 2 | Comparative fMptD-mediated ELISA analysis of recombinant $L$. salivarius cell lysate and whole-cell against MAP K-10 (A,B). Standard deviation of triplicate results is indicated by error
B

\section{Whole cells}

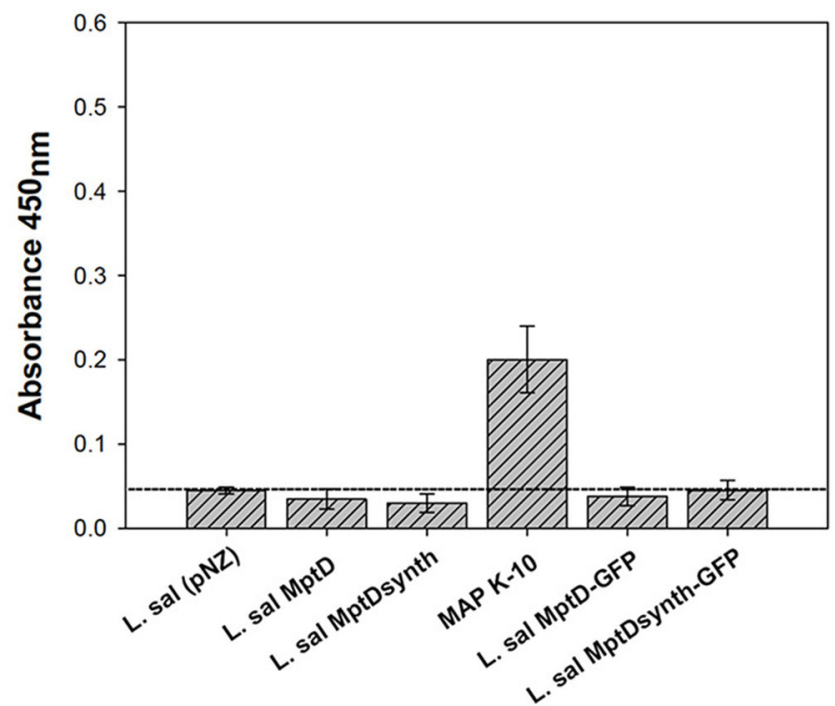

bars. Statistically significant difference was observed at $* P<0.05$. Horizontal dashed lines indicate the negative control threshold for each assay. 
of MMP (Bannantine et al., 2007). ELISA analysis with 8G2 on crude cell lysates of recombinant $L$. salivarius-MMP constructs revealed that the linear epitope could be detected in all MMP constructs (Figure 3A), with a significant 6.4-fold signal increase noted for the engineered MMPsynth compared to native MMP.

While microscopy data indicate that heterologously expressed MMP largely accumulates in the cytosol (Figure 1D), intriguingly, the engineered MMP was also detected during whole-cell ELISA using the 8G2 antibody (Figure 3B). Although these levels were low, the signal detected was approximate to that of the MAP $\mathrm{K}-10$ control strain (Figure 3B). Notably, as MMP expression is enhanced in L. salivarius, more protein is localized on the surface (Figure 3B).

\section{ELISA analysis with mAb $13 E 1$}

Analysis of L. salivarius cellular lysates with $13 \mathrm{E} 1$ indicated that the epitope recognized by this $\mathrm{mAb}$ is blocked when MMP is fused to GFP fusions (Figure 3C). However, this epitope appears to be restored by removal of the GFP tag, with 4fold higher levels of MMP detected from codon optimized MMPsynth when compared to the native gene $(P=0.0009)$, and 1.5-fold when compared to the MAP K-10 control strain $(P=0.003)$.

However, most intriguingly is that MMP protein could also be detected from whole cell $L$. salivarius MMPsynth using the 13E1 antibody, which was comparable to that in MAP K-10, albeit both were present at low levels (Figure 3D). While it has previously been indicated that MMP contains a 30 amino acid hydrophobic
A

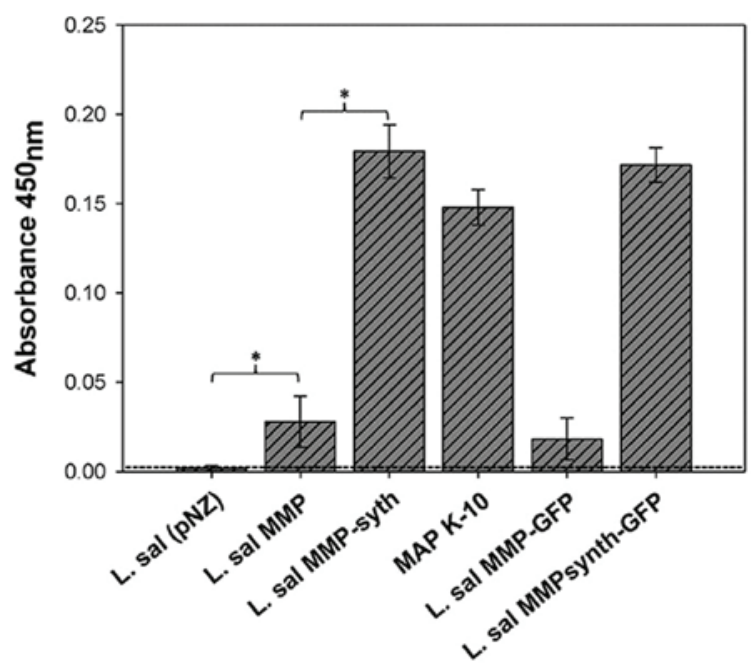

C

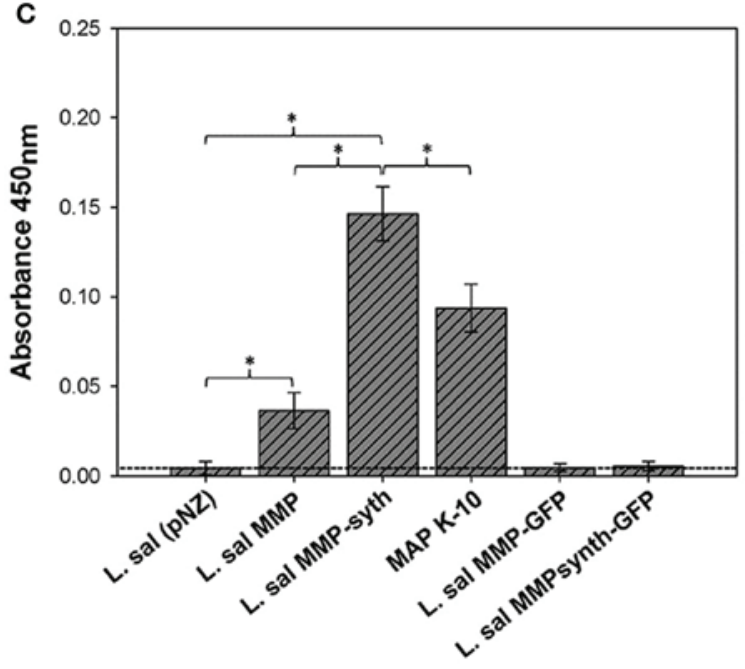

FIGURE 3 | Comparative ELISA analysis of recombinant $L$. salivarius cell-lysate and whole-cell against MAP K-10, using two monoclonal antibodies directed against MMP. The $8 \mathrm{G} 2$ antibody detects MMP (A,B) The MAb13E1 antibody detects a discontinuous epitope on MMP $(\mathbf{C}, \mathbf{D})$. The
B Whole cells

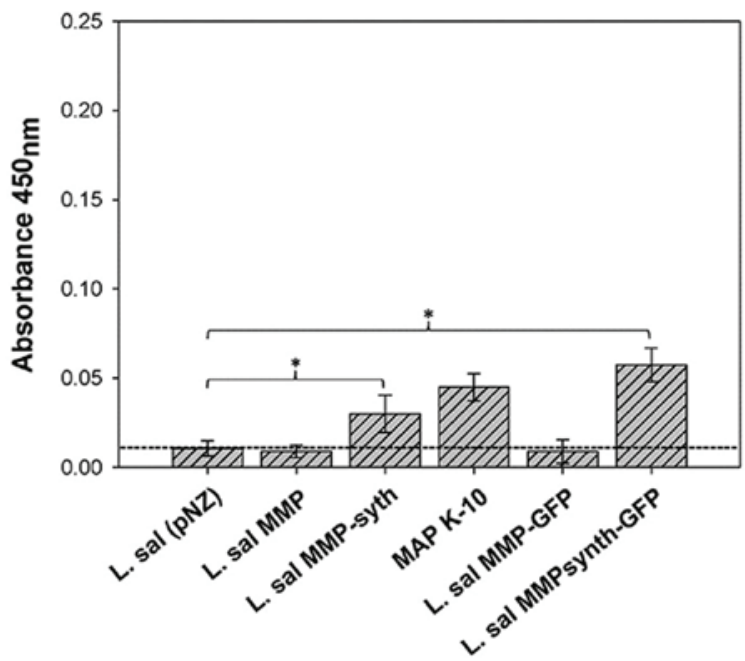

$8 \mathrm{G} 2$

D

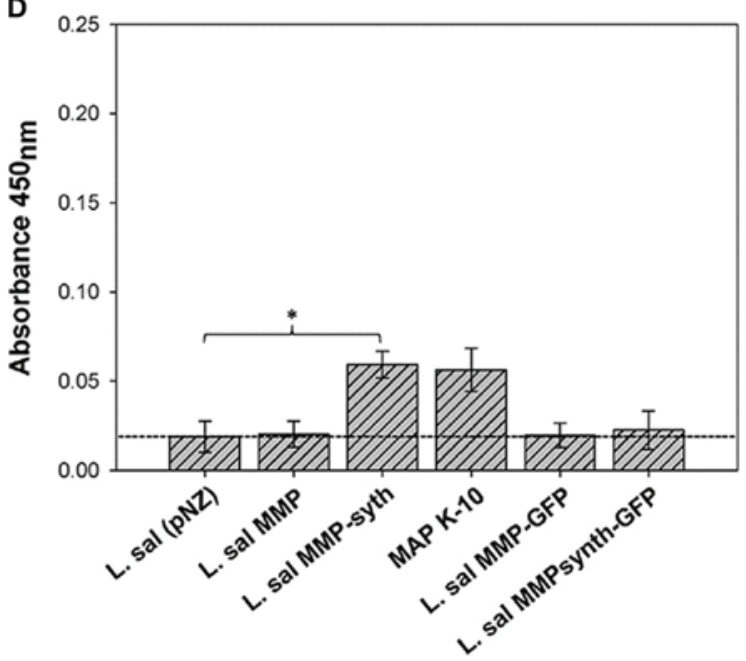

13E1

average value of $L$. sal MMP-GFP and $L$. sal MMP are below the negative control threshold. Standard deviation of triplicate results is indicated by error bars. Statistically significant difference was observed at $* P<0.05$. Horizontal dashed lines indicate the negative control threshold for each assay. 
domain near the C-terminal end suggestive of a membrane protein, the protein lacks a discernible $\mathrm{N}$-terminal signal sequence (Bannantine et al., 2003). Moreover, it has already been experimentally demonstrated that MMP is both surface exposed and actively shed from live MAP bacilli (Yakes et al., 2008), suggesting that MMP is translocated in a non-classical manner similar to other mycobacterial proteins (Pallen, 2002; Bendtsen et al., 2005).

\section{DISCUSSION}

There have been several efforts at heterologous expression of MAP proteins. E. coli expression of an impressive collection of over 650 MAP proteins has been constructed (Bannantine et al., 2010) and these proteins have been incorporated into a protein array to monitor antibody response in different disease stages (Bannantine et al., 2008). Efforts have also been devoted to in vitro transcription-translation (Li et al., 2007), but those efforts did not yield much protein to work with. Interestingly MMP was a test protein in that study as well. More recently, MAP proteins have been expressed in a Salmonella vaccine delivery strategy (Faisal et al., 2013). Our group is the first to use the probiotic genus Lactobacillus as a vaccine vector for MAP. We have overcome the limitations of low expression yields through re-engineering GCrich coding sequences. No efforts have been made to express MAP proteins in a faster growing species of Mycobacterium such as M. smegmatis.

We show that MptD, which contains six transmembrane domains, was targeted to the cell periphery, likely the cytoplasmic membrane, while MMP formed aggregates in the cytoplasm of L. salivarius. In general, proteins which are located within the cytoplasmic membrane must be targeted to a translocation site prior to their insertion and/or translocation (Fekkes and Driessen, 1999). However, in the case of MptD, such integral membrane proteins generally do not contain a signal sequence. Instead, their hydrophobic TMSs function as an internal signal for targeting and insertion which needs to be recognized early in the translocation pathway to prevent their aggregation in the cytoplasm (Fekkes and Driessen, 1999).

It is known that addition of any fusion tag to the N- or Ctermini of a peptide can modify specific structural characteristics either by sterically interfering with protein interactions or disrupting conformational folding (Snapp, 2009). The lack of $13 \mathrm{E} 1$ antibody recognition formed by MMP-GFP fusion led us to propose that the fluorescent foci within L. salivarius MMPsynthGFP were related to a masking effect of the MMP epitope with GFP and not representative of translational errors brought about through codon optimization. The GFP tag does not appear to impede localization of MMP at the cell surface, suggesting that this effect is steric at the C-terminus only and does not provide clues on secondary folding that might be required for localization. In originally isolating the 13E1 antibody, Bannantine and coworkers immunized mice with an N-terminal maltose-binding protein fusion with MMP (Bannantine et al., 2007). This suggests that the addition of a large $(\sim 40 \mathrm{kDa})$ protein tag at the $\mathrm{N}$ - terminus does not structurally impede the epitope of MMP. However, in our study GFP was at the C-terminus and while it is possible that the GFP tag might mask the 13E1 epitope irrespective of its fused location, it is also possible that the C-terminus is more heavily involved than the $\mathrm{N}$-terminal region in producing the epitope. In support of this, Li et al. (2007) expressed the MMP protein with a six-histidine tag at the $\mathrm{C}$-terminus, noting that the recombinant antigen could not be detected by MAP antibodies in pooled positive serum samples from cattle shedding MAP bacilli (Li et al., 2007).

Detailed studies have demonstrated that MMP is a surfacelocated virulence factor involved in mediating the invasion of bovine epithelial cells and is transcriptionally upregulated in oxygen limiting and solute stress conditions similar to those encountered within the intestine (Bannantine et al., 2003; Wu et al., 2007). Based upon in silico analysis MMP is structurally dissimilar to $\mathrm{MptD}$ and analysis lacks polytopic transmembrane domains or highly hydrophobic stretches. The aggregates observed were initially considered to be indicative of translational disorder through synonymous codon modification, since MMP expression in native MAP appears throughout the bacilli by electron microscopy (Bannantine et al., 2003). Alternatively, aggregation could be a consequence of $L$. salivarius reacting to over expression by inducing vesicle formation to compensate for inefficient processing or secretion of a non-host protein. Unfortunately, the negligible fluorescence for native MMP-GFP prevented direct comparison to determine if these foci also occurred in the absence of synonymous mutations necessitating use of the monoclonal antibody based ELISA.

The detection of a non-classically exported protein, such as MMP, from the extracellular surface of $L$. salivarius could indeed be attributed to cell lysis during experimental handling. However, this would presumably have also occurred for those L. salivarius cells expressing recombinant $\mathrm{MptD}$, yet this was not observed (Figure 2). Nevertheless, we acknowledge the behavior of the MMP recombinant strains may be different than the MptD recombinants and despite the lack of $\mathrm{AMptD}$ phage binding in whole cells, we cannot rule out cell lysis in the whole cell experiments with the MMP strains. As such, we have yet to determine the mechanism by which MMP was effectively presented in such a manner from our heterologous host strain.

Generally, there are three strategies available for the subcellular distribution of recombinant antigens from Lactobacillus based vaccine hosts and while cell surface display and secretion are favored, these can result in degradation of recombinant peptides due to exposure to proteolytic enzymes associated with gastric and pancreatic fluids (Kajikawa et al., 2011). Cytoplasmic expression on the other hand, subverts this and protects heterologously expressed peptides from degradation by encapsulation within the cytosol, as well as facilitating the accumulation of high concentrations of the antigenic component intracellularly (de Ruyter et al., 1996). As such, our L. salivarius MMPsynth host may provide an interesting combination of both high concentrations of cytoplasmically accumulated MMP, with the added advantage of superficial surface exposure.

Additionally, these results further demonstrate that heterologously expressed codon optimized $\mathrm{MptD}$ retains $\mathrm{fMptD}$ epitope presentation in L. salivarius. However, ELISA data also suggests that $\mathrm{MptD}$, or at least the epitope recognized by the 
fMptD phage, is not exposed on the surface of L. salivarius. It has already been shown that MptD expression on the cell surface of a recombinant host can be achieved using fMptD for both M. smegmatis and M. bovis BCG (Stratmann et al., 2004; Heinzmann et al., 2008); which could be due to the presence of mycobacterium specific chaperones facilitating appropriate presentation of the MptD protein (Goldstone et al., $2008)$. However, $m p t D$ is naturally present on a six gene operon $(m p t A-F)$ transcribed as a single polycistronic mRNA molecule [60] and in both the aforementioned studies, the recombinant hosts were not transformed with the $m p t D$ gene in isolation. The $M$. smegmatis harbored a vector including $m p t C-F$ genes of the mpt operon (Stratmann et al., 2004) while the M. bovis BCG host contained the entire operon integrated into the chromosome (Heinzmann et al., 2008). Consequently, it is possible that for effective MptD cell surface display, some ancillary Mpt proteins may also be required. The MptE protein (with five predicted TMSs) encoded by MAP3732c, located immediately downstream and overlapping the MAP3733c gene on the mpt operon, is a credible candidate in this respect owing to its association with the C-terminus of the $\mathrm{MptD}$ protein.

In future studies it may be interesting to ascertain if the sequential addition of this and other auxiliary mpt genes to L. salivarius enables native surface display of the MptD protein. Nevertheless, the lack of cell surface display may not be entirely disadvantageous in the context of a MAP antigen delivery host. The association of the MptD protein with the L. salivarius membrane, while incomplete, likely sequestered hydrophobic domains thus preventing undesirable aggregation and allowing higher levels of intracellular MptD to accumulate. Moreover it is clear from the analysis of cellular lysate that abundant MptD epitope could be detected within the cytoplasm, indicating that the synthetic gene and the L. salivarius host can effectively express and present $\mathrm{MptD}$ antigens.

\section{CONCLUSION}

In conclusion, we have demonstrated that the synonymous mutation of 279 rare or unfavorable codons within the MMP coding region facilitates improved protein synthesis within L. salivarius. Furthermore, both synthetic MMP and $\mathrm{MptD}$ proteins retain their epitopes or structural characteristics allowing them to effectively mimic the MAP expressed protein. Importantly, we also noted that while codon optimization enhances heterologous overexpression, the addition of a C-terminus GFP tag to both proteins may obstruct some conformational structure from forming.

Nevertheless, in the absence of a GFP tag and any extrinsic signaling peptide, both proteins displayed slight, yet noteworthy, tendencies to associate in the intended location within L. salivarius; MMP being detected on the cell surface, while the multiTMSs containing protein MptD associated with the cytoplasmic membrane boundary. This work underscores the potential of Lactobacillus salivarius to be used within a subunit vaccine development against MAP, as additional antigens are optimized for L. salivarius expression, the next step will require in-vivo testing to demonstrate true efficacy.

\section{FUNDING INFORMATION}

The author's acknowledge the financial assistance of the Irish Government through funding under the Food Institutional Research Measure (FIRM) grant 08RDCIT617 as well as the USDA-Agricultural Research Service.

\section{ACKNOWLEDGMENTS}

The authors thank Norman Stern for providing the Lactobacillus salivarius NRRL B-30514 strain, Gerald F. Gerlach for providing the $\mathrm{fMptD}$ bacteriophage, and Alan Lucid for his assistance with bioinformatic analysis. The technical assistance of Janis K. Hansen at the USDA's National Animal Disease Center is gratefully acknowledged.

\section{SUPPLEMENTARY MATERIAL}

The Supplementary Material for this article can be found online at: http://www.frontiersin.org/journal/10.3389/fcimb. 2014.00120/abstract

\section{REFERENCES}

Banasure, K. D., Basagoudanavar, S. H., Chaudhury, P., Tiwari, V., Parihar, N. S., and Goswami, P. P. (2001). Identification and characterization of a gene encoding a $35-\mathrm{kDa}$ protein from Mycobacterium avium subspecies paratuberculosis. FEMS Microbiol. Lett. 196, 195-199. doi: 10.1111/j.1574-6968.2001.tb10564.x

Bannantine, J. P., and Bermudez, L. E. (2013). No holes barred: invasion of the intestinal mucosa by Mycobacterium avium subsp. paratuberculosis. Infect Immun. 81, 3960-3965. doi: 10.1128/IAI.00575-13

Bannantine, J. P., Huntley, J. F., Miltner, E., Stabel, J. R., and Bermudez, L. E. (2003). The Mycobacterium avium subsp. paratuberculosis $35 \mathrm{kDa}$ protein plays a role in invasion of bovine epithelial cells. Microbiology 149, 2061-2069. doi: 10.1099/mic.0.26323-0

Bannantine, J. P., Li, L., Mwangi, M., Cote, R., Raygoza Garay, J. A., and Kapur, V. (2014). Complete genome sequence of Mycobacterium avium subsp. paratuberculosis, isolated from human breast milk. Genome Announc. 2:e0125213. doi: 10.1128/genomeA.01252-13

Bannantine, J. P., Paustian, M. L., Waters, W. R., Stabel, J. R., Palmer, M. V., Li, L., et al. (2008). Profiling bovine antibody responses to Mycobacterium avium subsp. paratuberculosis infection by using protein arrays. Infect Immun. 76, 739-749. doi: 10.1128/IAI.00915-07

Bannantine, J. P., Radosevich, T. J., Stabel, J. R., Berger, S., Griffin, J. F., and Paustian, M. L. (2007). Production and characterization of monoclonal antibodies against a major membrane protein of Mycobacterium avium subsp. paratuberculosis. Clin. Vaccine Immunol. 14, 312-317. doi: 10.1128/CVI. 00353-06

Bannantine, J. P., Stabel, J. R., Bayles, D. O., and Geisbrecht, B. V. (2010). Characteristics of an extensive Mycobacterium avium subspecies paratuberculosis recombinant protein set. Protein Expr. Purif. 72, 223-233. doi: 10.1016/j.pep.2010.03.019

Bastida, F., and Juste, R. A. (2011). Paratuberculosis control: a review with a focus on vaccination. J. Immune Based Ther. Vaccines 9:8. doi: 10.1186/14768518-9-8

Bendtsen, J. D., Kiemer, L., Fausboll, A., and Brunak, S. (2005). Non-classical protein secretion in bacteria. BMC Microbiol. 5:58. doi: 10.1186/1471-2180-5-58

Bermudez-Humaran, L. G., Kharrat, P., Chatel, J. M., and Langella, P. (2011). Lactococci and lactobacilli as mucosal delivery vectors for therapeutic proteins and DNA vaccines. Microb. Cell Fact. 10(Suppl. 1), S4. doi: 10.1186/1475-285910-S1-S4

Brown, M. C., Joaquim, T. R., Chambers, R., Onisk, D. V., Yin, F., Moriango, J. M., et al. (2011). Impact of immunization technology and assay application on antibody performance-a systematic comparative evaluation. PLOS ONE 6:e28718. doi: 10.1371/journal.pone.0028718

Buchan, J. R., and Stansfield, I. (2007). Halting a cellular production line: responses to ribosomal pausing during translation. Biol. Cell 99, 475-487. doi: 10.1042/BC20070037 
Buddle, B. M., Wilson, T., Denis, M., Greenwald, R., Esfandiari, J., Lyashchenko, K. P., et al. (2010). Sensitivity, specificity, and confounding factors of novel serological tests used for the rapid diagnosis of bovine tuberculosis in farmed red deer (Cervus elaphus). Clin. Vaccine Immunol. 17, 626-630. doi: 10.1128/CVI. 00010-10

Bull, T. J., Gilbert, S. C., Sridhar, S., Linedale, R., Dierkes, N., Sidi-Boumedine, K., et al. (2007). A novel multi-antigen virally vectored vaccine against Mycobacterium avium subspecies paratuberculosis. PLoS ONE 2:e1229. doi: 10.1371/journal.pone.0001229

Campos, I. B., Darrieux, M., Ferreira, D. M., Miyaji, E. N., Silva, D. A., Areas, A. P., et al. (2008). Nasal immunization of mice with Lactobacillus casei expressing the Pneumococcal Surface Protein A: induction of antibodies, complement deposition and partial protection against Streptococcus pneumoniae challenge. Microbes Infect. 10, 481-488. doi: 10.1016/j.micinf.2008.01.007

Chacon, O., Bermudez, L. E., and Barletta, R. G. (2004). Johne's disease, inflammatory bowel disease, and Mycobacterium paratuberculosis. Annu. Rev. Microbiol. 58, 329-363. doi: 10.1146/annurev.micro.58.030603.123726

Chappel, J. A., He, M., and Kang, A. S. (1998). Modulation of antibody display on M13 filamentous phage. J. Immunol. Methods 221, 25-34. doi: 10.1016/S00221759(98)00094-5

Coad, M., Clifford, D. J., Vordermeier, H. M., and Whelan, A. O. (2013). The consequences of vaccination with the Johne's disease vaccine, Gudair, on diagnosis of bovine tuberculosis. Vet. Rec. 172, 266. doi: 10.1136/vr.101201

Cossu, A., Rosu, V., Paccagnini, D., Cossu, D., Pacifico, A., and Sechi, L. A. (2011). MAP3738c and MptD are specific tags of Mycobacterium avium subsp. paratuberculosis infection in type I diabetes mellitus. Clin. Immunol. 141, 49-57. doi: 10.1016/j.clim.2011.05.002

de Ruyter, P. G., Kuipers, O. P., and De Vos, W. M. (1996). Controlled gene expression systems for Lactococcus lactis with the food-grade inducer nisin. Appl. Environ. Microbiol. 62, 3662-3667.

Douarre, P. E., Cashman, W., Buckley, J., Coffey, A., and O'mahony, J. M. (2010). Isolation and detection of Mycobacterium avium subsp. paratuberculosis (MAP) from cattle in Ireland using both traditional culture and molecular based methods. Gut Pathog. 2:11. doi: 10.1186/1757-4749-2-11

Drew, D., Slotboom, D. J., Friso, G., Reda, T., Genevaux, P., Rapp, M., et al. (2005). A scalable, GFP-based pipeline for membrane protein overexpression screening and purification. Protein Sci. 14, 2011-2017. doi: 10.1110/ps.0514 66205

Faisal, S. M., Yan, F., Chen, T. T., Useh, N. M., Guo, S., Yan, W., et al. (2013). Evaluation of a Salmonella vectored vaccine expressing Mycobacterium avium subsp. paratuberculosis antigens against challenge in a goat model. PLoS ONE 8:e70171. doi: 10.1371/journal.pone.0070171

Fekkes, P., and Driessen, A. J. (1999). Protein targeting to the bacterial cytoplasmic membrane. Microbiol. Mol. Biol. Rev. 63, 161-173.

Goldstone, R. M., Moreland, N. J., Bashiri, G., Baker, E. N., and Shaun Lott, J. (2008). A new Gateway vector and expression protocol for fast and efficient recombinant protein expression in Mycobacterium smegmatis. Protein Expr. Purif. 57, 81-87. doi: 10.1016/j.pep.2007.08.015

Gurung, R. B., Purdie, A. C., Begg, D. J., and Whittington, R. J. (2012). In silico screened Mycobacterium avium subsp. paratuberculosis (MAP) recombinant proteins upregulated under stress conditions are immunogenic in sheep. Vet. Immunol. Immunopathol. 149, 186-196. doi: 10.1016/j.vetimm.2012. 06.026

He, Z., and De Buck, J. (2010). Localization of proteins in the cell wall of Mycobacterium avium subsp. paratuberculosis K10 by proteomic analysis. Proteome Sci. 8:21. doi: 10.1186/1477-5956-8-21

Heinzmann, J., Wilkens, M., Dohmann, K., and Gerlach, G. F. (2008). Mycobacterium avium subsp. paratuberculosis-specific mpt operon expressed in M. bovis BCG as vaccine candidate. Vet. Microbiol. 130, 330-337. doi: 10.1016/j.vetmic.2008.01.014

Hines, M. E., Turnquist, S. E., Ilha, M. R., Rajeev, S., Jones, A. L., Whittington, L., et al. (2014). Evaluation of novel oral vaccine candidates and validation of a caprine model of Johne's disease. Front. Microbiol. 4:26. doi: 10.3389/fcimb.2014.00026

Johnston, C., Douarre, P. E., Soulimane, T., Pletzer, D., Weingart, H., Macsharry, J., et al. (2013). Codon optimisation to improve expression of a Mycobacterium avium ssp. paratuberculosis-specific membrane-associated antigen by Lactobacillus salivarius. Pathog. Dis. 68, 27-38. doi: 10.1111/2049632X. 12040
Kajikawa, A., Nordone, S. K., Zhang, L., Stoeker, L. L., Lavoy, A. S., Klaenhammer, T. R., et al. (2011). Dissimilar properties of two recombinant Lactobacillus acidophilus strains displaying Salmonella FliC with different anchoring motifs. Appl. Environ. Microbiol. 77, 6587-6596. doi: 10.1128/AEM. 05153-11

Koets, A., Hoek, A., Langelaar, M., Overdijk, M., Santema, W., Franken, P., et al. (2006). Mycobacterial $70 \mathrm{kD}$ heat-shock protein is an effective subunit vaccine against bovine paratuberculosis. Vaccine 24, 2550-2559. doi: 10.1016/j.vaccine.2005.12.019

Kohler, H., Gyra, H., Zimmer, K., Drager, K. G., Burkert, B., Lemser, B., et al. (2001). Immune reactions in cattle after immunization with a Mycobacterium paratuberculosis vaccine and implications for the diagnosis of $M$. paratuberculosis and M. bovis infections. J. Vet. Med. B Infect. Dis. Vet. Public Health 48, 185-195. doi: 10.1046/j.1439-0450.2001.00443.x

Li, L., Bannantine, J. P., Zhang, Q., Amonsin, A., May, B. J., Alt, D., et al. (2005). The complete genome sequence of Mycobacterium avium subspecies paratuberculosis. Proc. Natl. Acad. Sci. U.S.A. 102, 12344-12349. doi: 10.1073/pnas.0505662102

Li, L., Munir, S., Bannantine, J. P., Sreevatsan, S., Kanjilal, S., and Kapur, V. (2007). Rapid expression of Mycobacterium avium subsp. paratuberculosis recombinant proteins for antigen discovery. Clin. Vaccine Immunol. 14, 102-105. doi: 10.1128/CVI.00138-06

Magnan, C. N., Randall, A., and Baldi, P. (2009). SOLpro: accurate sequencebased prediction of protein solubility. Bioinformatics 25, 2200-2207. doi: 10.1093/bioinformatics/btp386

Martin, E., Roche, P. W., Triccas, J. A., and Britton, W. J. (2001). DNA encoding a single mycobacterial antigen protects against leprosy infection. Vaccine 19, 1391-1396. doi: 10.1016/S0264-410X(00)00374-1

Messaoudi, S., Madi, A., Prevost, H., Feuilloley, M., Manai, M., Dousset, X., et al. (2012). In vitro evaluation of the probiotic potential of Lactobacillus salivarius SMXD51. Anaerobe 18, 584-589. doi: 10.1016/j.anaerobe.2012. 10.004

Mohamadzadeh, M., Duong, T., Sandwick, S. J., Hoover, T., and Klaenhammer, T. R. (2009). Dendritic cell targeting of Bacillus anthracis protective antigen expressed by Lactobacillus acidophilus protects mice from lethal challenge. Proc. Natl. Acad. Sci. U.S.A. 106, 4331-4336. doi: 10.1073/pnas.09000 29106

Mohamadzadeh, M., Durmaz, E., Zadeh, M., Pakanati, K. C., Gramarossa, M., Cohran, V., et al. (2010). Targeted expression of anthrax protective antigen by Lactobacillus gasseri as an anthrax vaccine. Future Microbiol. 5, 1289-1296. doi: $10.2217 / \mathrm{fmb} .10 .78$

Pallen, M. J. (2002). The ESAT-6/WXG100 superfamily-and a new Grampositive secretion system? Trends Microbiol. 10, 209-212. doi: 10.1016/S0966$842 \mathrm{X}(02) 02345-4$

Pavan, S., Hols, P., Delcour, J., Geoffroy, M. C., Grangette, C., Kleerebezem, M., et al. (2000). Adaptation of the nisin-controlled expression system in Lactobacillus plantarum: a tool to study in vivo biological effects. Appl. Environ. Microbiol. 66, 4427-4432. doi: 10.1128/AEM.66.10.4427-44 32.2000

Rosseels, V., and Huygen, K. (2008). Vaccination against paratuberculosis. Expert Rev. Vaccines 7, 817-832. doi: 10.1586/14760584. 7.6.817

Rosu, V., Ahmed, N., Paccagnini, D., Gerlach, G., Fadda, G., Hasnain, S. E., et al. (2009). Specific immunoassays confirm association of Mycobacterium avium Subsp. paratuberculosis with type-1 but not type-2 diabetes mellitus. PLoS ONE 4:e4386. doi: 10.1371/journal.pone.0004386

Sambrook, J., Fritsch, E. F., and Maniatis, T. (1990). Molecular-cloning-a laboratory manual, 2nd Edition. Nature 343, 604-660.

Scandurra, G. M., De Lisle, G. W., Cavaignac, S. M., Young, M., Kawakami, R. P., and Collins, D. M. (2010). Assessment of live candidate vaccines for paratuberculosis in animal models and macrophages. Infect. Immun. 78, 1383-1389. doi: 10.1128/IAI.01020-09

Shin, S. J., Wu, C. W., Steinberg, H., and Talaat, A. M. (2006). Identification of novel virulence determinants in Mycobacterium paratuberculosis by screening a library of insertional mutants. Infect. Immun. 74, 3825-3833. doi: 10.1128/IAI. 01742-05

Sleator, R. D., and Hill, C. (2008). Designer probiotics: a potential therapeutic for Clostridium difficile? J. Med. Microbiol. 57, 793-794. doi: 10.1099/jmm.0. 47697-0 
Snapp, E. L. (2009). Fluorescent proteins: a cell biologist's user guide. Trends Cell Biol. 19, 649-655. doi: 10.1016/j.tcb.2009.08.002

Stern, N. J., Svetoch, E. A., Eruslanov, B. V., Perelygin, V. V., Mitsevich, E. V., Mitsevich, I. P., et al. (2006). Isolation of a Lactobacillus salivarius strain and purification of its bacteriocin, which is inhibitory to Campylobacter jejuni in the chicken gastrointestinal system. Antimicrob. Agents Chemother. 50, 3111-3116. doi: 10.1128/AAC.00259-06

Stratmann, J., Dohmann, K., Heinzmann, J., and Gerlach, G. F. (2006). Peptide aMptD-mediated capture PCR for detection of Mycobacterium avium subsp. paratuberculosis in bulk milk samples. Appl. Environ. Microbiol. 72, 5150-5158. doi: 10.1128/AEM.00590-06

Stratmann, J., Strommenger, B., Goethe, R., Dohmann, K., Gerlach, G. F., Stevenson, K., et al. (2004). A 38-kilobase pathogenicity island specific for Mycobacterium avium subsp. paratuberculosis encodes cell surface proteins expressed in the host. Infect Immun. 72, 1265-1274. doi: 10.1128/IAI.72.3.12651274.2004

Triccas, J. A., Roche, P. W., Winter, N., Feng, C. G., Butlin, C. R., and Britton, W. J. (1996). A 35-kilodalton protein is a major target of the human immune response to Mycobacterium leprae. Infect. Immun. 64, 5171-5177.

Triccas, J. A., Winter, N., Roche, P. W., Gilpin, A., Kendrick, K. E., and Britton, W. J. (1998). Molecular and immunological analyses of the Mycobacterium avium homolog of the immunodominant Mycobacterium leprae 35-kilodalton protein. Infect. Immun. 66, 2684-2690.

Vrieling, M., Santema, W., Vordermeier, M., Rutten, V., and Koets, A. (2013). Hsp70 vaccination-induced primary immune responses in efferent lymph of the draining lymph node. Vaccine 31, 4720-4727. doi: 10.1016/j.vaccine.2013. 08.021

Wang, Z., Yu, Q., Gao, J., and Yang, Q. (2012). Mucosal and systemic immune responses induced by recombinant Lactobacillus spp. expressing the hemagglutinin of the avian influenza virus H5N1. Clin. Vaccine Immunol. 19, 174-179. doi: 10.1128/CVI.05618-11

Winter, N., Triccas, J. A., Rivoire, B., Pessolani, M. C., Eiglmeier, K., Lim, E. M., et al. (1995). Characterization of the gene encoding the immunodominant $35 \mathrm{kDa}$ protein of Mycobacterium leprae. Mol. Microbiol. 16, 865-876. doi: 10.1111/j.1365-2958.1995.tb02314.x
Wu, C. W., Schmoller, S. K., Shin, S. J., and Talaat, A. M. (2007). Defining the stressome of Mycobacterium avium subsp. paratuberculosis in vitro and in naturally infected cows. J. Bacteriol. 189, 7877-7886. doi: 10.1128/JB. 00780-07

Yakes, B. J., Lipert, R. J., Bannantine, J. P., and Porter, M. D. (2008). Impact of protein shedding on detection of Mycobacterium avium subsp. paratuberculosis by a whole-cell immunoassay incorporating surface-enhanced Raman scattering. Clin. Vaccine Immunol. 15, 235-242. doi: 10.1128/CVI. 00335-07

Yu, Q., Zhu, L., Kang, H., and Yang, Q. (2013). Mucosal Lactobacillus vectored vaccines. Hum. Vaccin. Immunother. 9, 805-807. doi: 10.4161/ hv.23302

Conflict of Interest Statement: The Associate Editor Dr. Adel Talaat declares that despite having collaborated with the author Dr. John Bananntine, the review process was handled objectively and no conflict of interest exists. The authors declare that the research was conducted in the absence of any commercial or financial relationships that could be construed as a potential conflict of interest.

Received: 24 April 2014; accepted: 15 August 2014; published online: 04 September 2014.

Citation: Johnston CD, Bannantine JP, Govender R, Endersen L, Pletzer D, Weingart H, Coffey A, O'Mahony J and Sleator RD (2014) Enhanced expression of codon optimized Mycobacterium avium subsp. paratuberculosis antigens in Lactobacillus salivarius. Front. Cell. Infect. Microbiol. 4:120. doi: 10.3389/fcimb.2014.00120

This article was submitted to the journal Frontiers in Cellular and Infection Microbiology.

Copyright (c) 2014 Johnston, Bannantine, Govender, Endersen, Pletzer, Weingart, Coffey, O'Mahony and Sleator. This is an open-access article distributed under the terms of the Creative Commons Attribution License (CC BY). The use, distribution or reproduction in other forums is permitted, provided the original author(s) or licensor are credited and that the original publication in this journal is cited, in accordance with accepted academic practice. No use, distribution or reproduction is permitted which does not comply with these terms. 